\title{
Effect of Technological Parameters of Machining on Energy Efficiency in Face Milling of Heat-Treated Oak Wood
}

Peter Koleda, * Štefan Barcík, and Adriana Nociarová

This paper examines the influence of technological parameters on electrical power in the plane milling of native and modified oak wood. Milling was performed under various cutting conditions, including cutting speeds of 20,40, and $60 \mathrm{~m} \mathrm{~s}^{-1}$, feed rates of 6,10 , and $15 \mathrm{~m} \mathrm{~min}^{-1}$, and cutting edge angles of 15,20 , and $30^{\circ}$ on five different samples of oak wood. The wood was native and heat-treated at temperatures of 160, 180, 210 , and $240{ }^{\circ} \mathrm{C}$. An analysis of variance and post-hoc Duncan test revealed the influence of the examined parameters on the energy consumption of milling, whereby the cutting speed was the most statistically significant parameter and was directly dependent on the speed of the asynchronous motor and the moment transmission to the miller spindle.

Keywords: ThermoWood; Milling; Technological parameters; Input power

Contact information: Department of Manufacturing and Automation Technology, Faculty of Environmental and Manufacturing Technology, Technical University in Zvolen, Studentska 26, 96053 Zvolen, Slovakia;

* Corresponding author: peter.koleda@tuzvo.sk

\section{INTRODUCTION}

Wood has a very wide range of uses, especially in construction, furniture, paper, and transportation. A very important feature of wood is its natural durability in various exterior and more demanding indoor exposures. The properties of wood materials can be changed and improved by thermal and hydrothermal wood treatment at high temperatures of 150 to $260{ }^{\circ} \mathrm{C}$ (Boonstra et al. 2007). The high temperatures degrade wood's structural polymers to form new water-insoluble substances and substances with a toxic or repellent effect against biological pests of wood. Strength and some mechanical properties decrease in heat-treated wood due to the decrease in density (Vančo et al. 2017a), as well as the disruption of hemicellulose and increased hydrophobicity of the surface (Barcík and Homola 2004; Niemz et al. 2010). The mechanical properties are significantly reduced if the heat treatment of the wood is carried out in an inert environment without access of oxygen, such as in a vacuum, nitrogen, or oil (Reinprecht 2008; Safin et al. 2015).

At temperatures above 150 to $170{ }^{\circ} \mathrm{C}$, in addition to plasticizing processes, the chemical structure of the treated wood begins to change significantly. Hydrophilic functional groups begin to disappear in structures of the polysaccharides, lignin, and accompanying materials. Depolymerization and condensation reactions are carried out in conjunction with partial carbonization of the wood and the release of flammable gases. Due to the aforementioned changes in the heat-treated wood, the wood becomes more resistant to biological pests and its hygroscopicity decreases (Zobel and Sprangue 1998; Bengtsoon et al. 2003; Reinprecht 2008). 
Working heat-treated wood, either by machine or manually, has its disadvantages compared to ordinary wood. When machining heat-treated wood, the blade must be well sharpened; because cutting surfaces are smoother, the cutting force is reduced. The problem with machining heat-treated wood is the formation of fine dust that pollutes the work environment. The dust can also cause health problems for service personnel. Therefore, it is necessary to capture the resulting fraction during machining using special suction hoods to avoid inhalation of this dust. Another unpleasant fact about machining heat-treated wood is the specific odor generated by the release of the aromatic compounds (Reinprecht and Vilholdová 2008). The course of the blade in milling is a cycloid because the cutting speed is much higher than the feed rate. The cutting path is a circle (Prokes 1982; Lisičan 1996). In practice, it is very important that the entire woodworking process proceeds with the smallest energy demand, while attaining the desired properties and quality of the machined surface (Thiede et al. 2012). Several factors influence the power demand of machinery, such as the selection of the appropriate cutting tool material, the geometry of the cutting tool, optimal cutting conditions (cutting speed, feed rate, tooth movement), and the cutting power.

Cutting input and output power are the basic criteria for the evaluation of woodworking machines. The energy demand of the cutting process is most frequently observed by means of cutting power (Barcík and Rehák 2009). Cutting power is the power that is required to allow the tool blades to cut off chips. It is the result of the scalar component of the force vector and the cutting speed vector, which is shown in Eq. 1,

$$
P_{c}=F_{c} \cdot v_{c}
$$

where $P_{c}$ is cutting power $(\mathrm{W}), F_{c}$ is vector of force $(\mathrm{N})$, and $v_{c}$ is cutting speed vector (m $\left.\mathrm{s}^{-1}\right)$.

With the known milling technology parameters, the cutting power can be determined as shown in Eq. 2 (Olteanu et al. 2013),

$$
P_{c}=\frac{a_{p} \cdot a_{e} \cdot v_{f} \cdot k_{c}}{60 \cdot 10^{3}}
$$

where $a_{p}$ is the cut depth $(\mathrm{mm}), a_{e}$ is the cut width $(\mathrm{mm}), v_{f}$ is feed rate $\left(\mathrm{mm} \mathrm{min}^{-1}\right)$, and $k_{c}$ is specific cutting force $\left(\mathrm{N} \mathrm{mm}^{-2}\right)$.

The input power of the motor $P_{p}$ is the product of the voltage, current, and power factor. Power is an important parameter necessary to determine energy costs and to determine the load of electric power cables. Input power is calculated in Eq. 3,

$$
P_{p}=U \cdot I \cdot \cos \varphi
$$

where $U$ is electric voltage (V), $I$ is electric current (A), and $\cos \varphi$ is power factor (-).

If the machine is connected in a three-phase system, the power input of the electric motor is calculated from Eq. 4, which shows it as the sum of inputs per phase (Barcík 2009).

$$
P=U_{1} \cdot I_{1} \cdot \cos \varphi_{1}+U_{2} \cdot I_{2} \cdot \cos \varphi_{2}+U_{3} \cdot I_{3} \cdot \cos \varphi_{3}
$$

In Eq. $4, U_{1,2,3}$ are phase electric voltages $(\mathrm{V}), I_{1,2,3}$ are electric currents $(\mathrm{A})$, and $\cos \varphi_{1,2,3}$ are power factors (-).

The goal of this experiment was to determine the dependence of total input power 
for the milling of selected wood species on the temperature of the heat treatment of wood.

\section{EXPERIMENTAL}

Samples of 96-year-old Quercus robur from Vlčí jarok (Budča, Slovak Republic) were used in the experimental tests (Koleda et al. 2017).

Lumber measuring $25 \mathrm{~mm}$ thick was cut from logs with a diameter of 350 to 400 mm using a band saw. Subsequently, the wood was dried to a moisture of $10 \%$. The dried wood was cut to obtain a lateral tangential lumber with a $110 \mathrm{~mm}$ width. By aligning on the grinding and pull milling cutters, the thickness was adjusted to $20 \mathrm{~mm}$. Cuts were made using a 500-mm circular saw, followed by heat treatment in a high temperature furnace at Forestry Faculty in Russia. Two cuts were left natural, and the other eight were heat-treated to the appropriate temperature $\left(160{ }^{\circ} \mathrm{C}, 180{ }^{\circ} \mathrm{C}, 210{ }^{\circ} \mathrm{C}\right.$, and $\left.240{ }^{\circ} \mathrm{C}\right)$. The heat treatment process is illustrated in Fig. 1. The time intervals of the individual phases and wood density are shown in Table 1 (Vančo et al. 2017b). The heat-treated samples had a humidity of 3 to 6\%, which was measured with the Wagner L6006 humidifier (Kazan, Russia), prior to experimental measurement (Barcík et al. 2014).

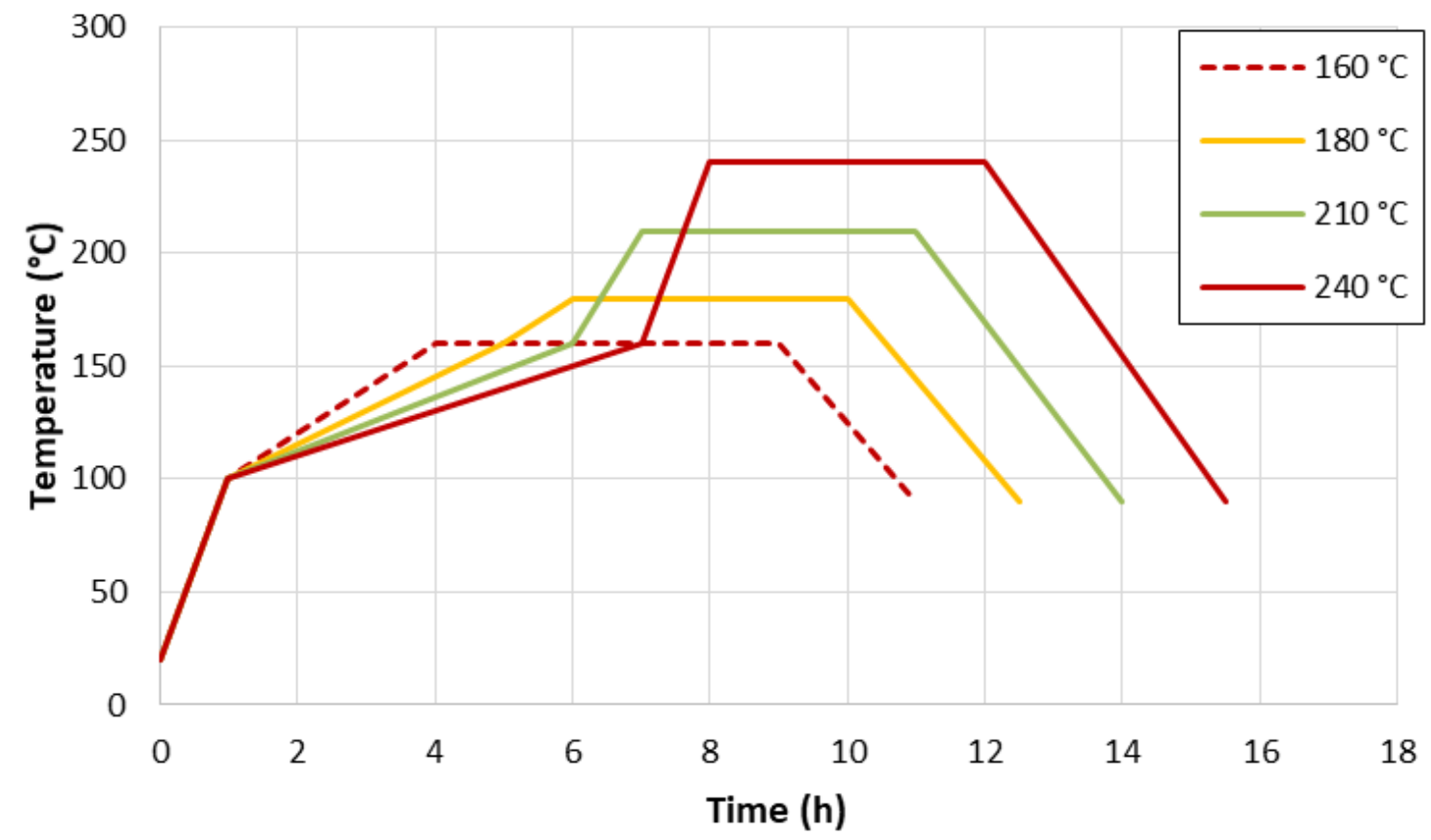

Fig. 1. Phases of thermal modification

Table 1. Times of Thermal Modification and Wood Density

\begin{tabular}{|c|c|c|c|c|c|}
\hline $\begin{array}{c}\text { Temperature } \\
\left({ }^{\circ} \mathrm{C}\right)\end{array}$ & 1. phase $(\mathrm{h})$ & 2. phase $(\mathrm{h})$ & 3. phase $(\mathrm{h})$ & $\begin{array}{c}\text { Density } \rho \\
\left(\mathrm{kg} \cdot \mathrm{m}^{-3}\right)^{*}\end{array}$ & $\begin{array}{c}\text { Change of density } \\
\text { from natural }(\%)\end{array}$ \\
\hline 160 & 4 & 5 & 2 & 622 & 2.71 \\
\hline 180 & 5 & 5 & 2,5 & 619 & 3.23 \\
\hline 210 & 6 & 5 & 3 & 588 & 8.67 \\
\hline 240 & 7 & 5 & 3,5 & 571 & 11.9 \\
\hline
\end{tabular}




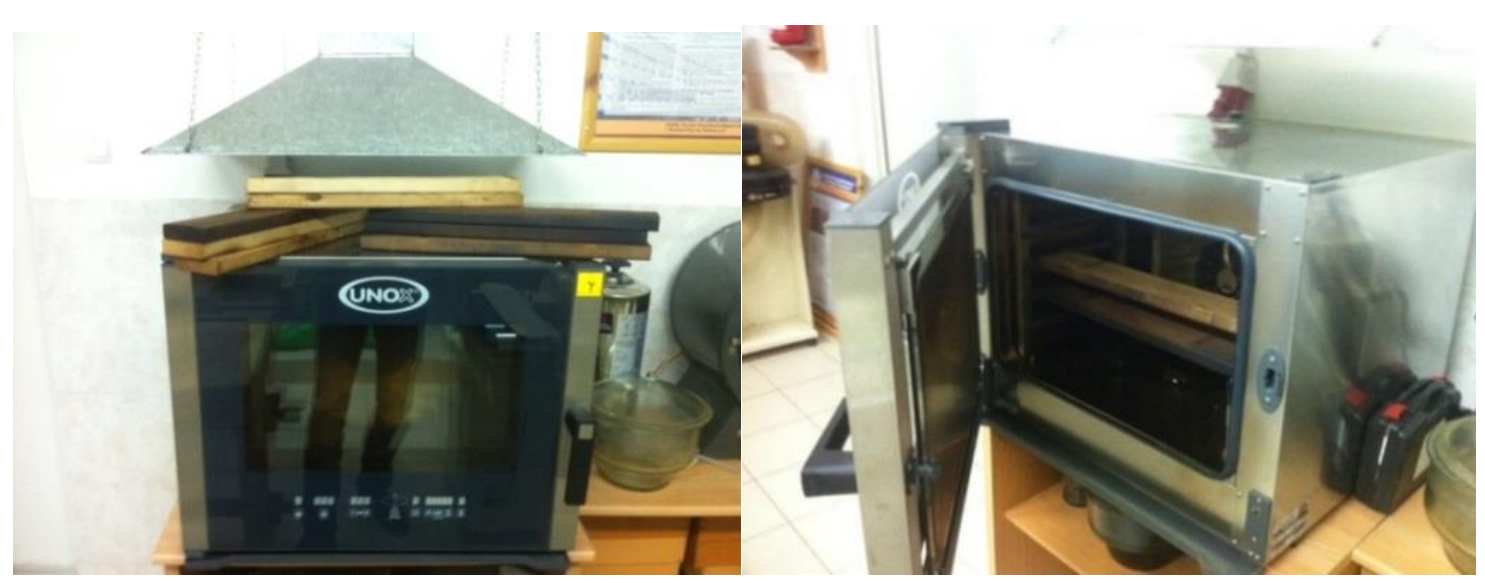

Fig. 2. Equipment for thermal modification - high temperature furnace

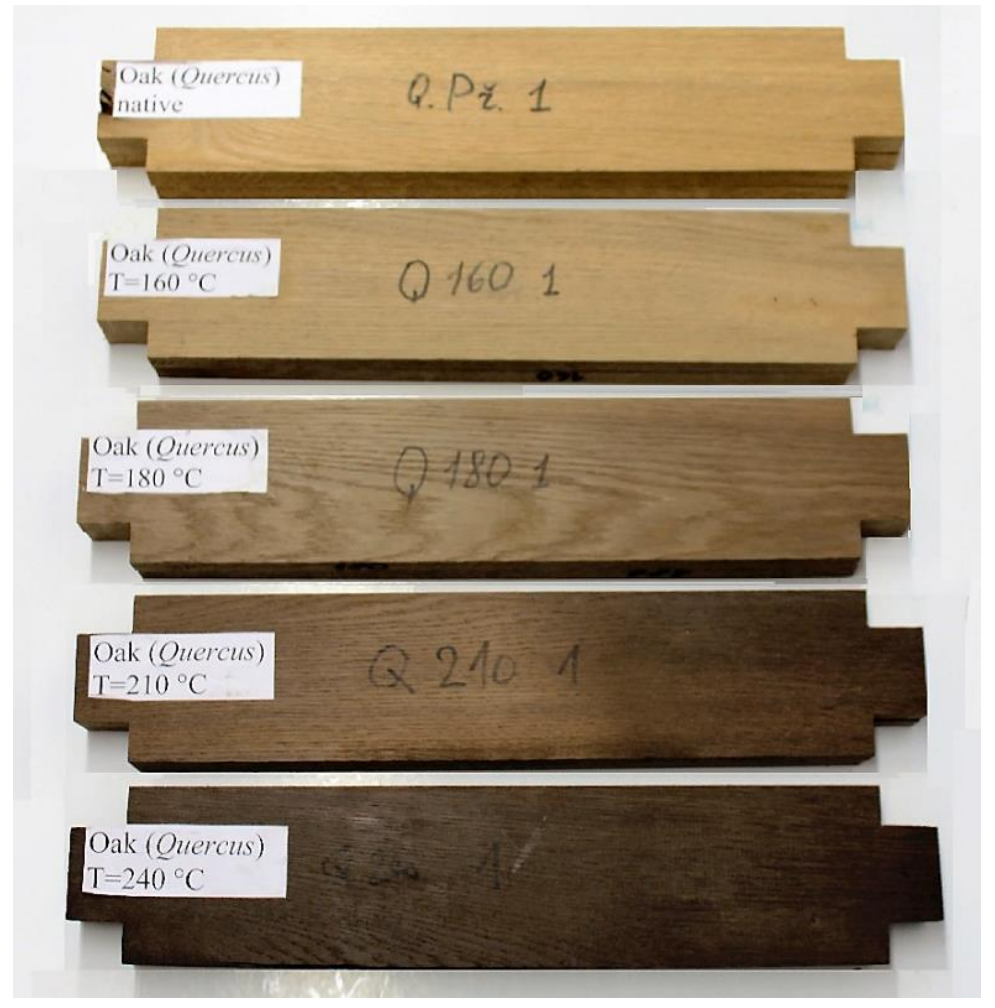

Fig. 3. Wood samples before measurement

The high-temperature furnace for the thermal treatment is shown in Fig. 2, and the samples prepared for milling are shown in Fig. 3.

All practical tests were carried out by an experimental device (Figs. 4 and 5), which is in the development workshops of Technical University in Zvolen. The experiment was carried out using the following operations and machinery:

- planar milling - lower spindle miller FVS

- feed of material - feed device Frommia

- current and voltage measurement - Power Analyzer DW6090 


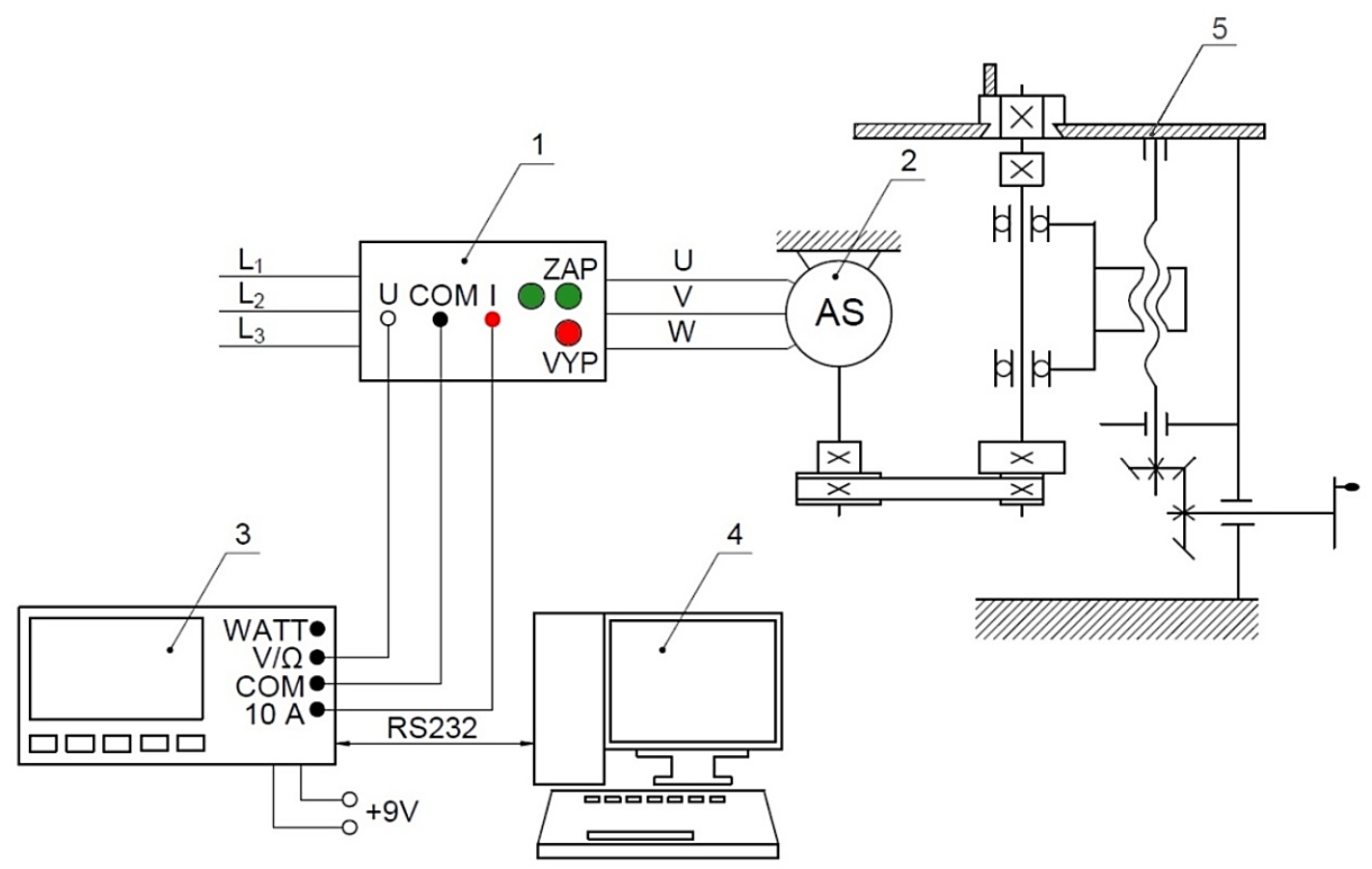

Fig. 4. Diagram of experimental equipment for measuring power: 1 - switch $U, I, 2$ - asynchronous motor, 3 - power analyser DW 6090, 4 - laptop, 5 - milling machine SVF
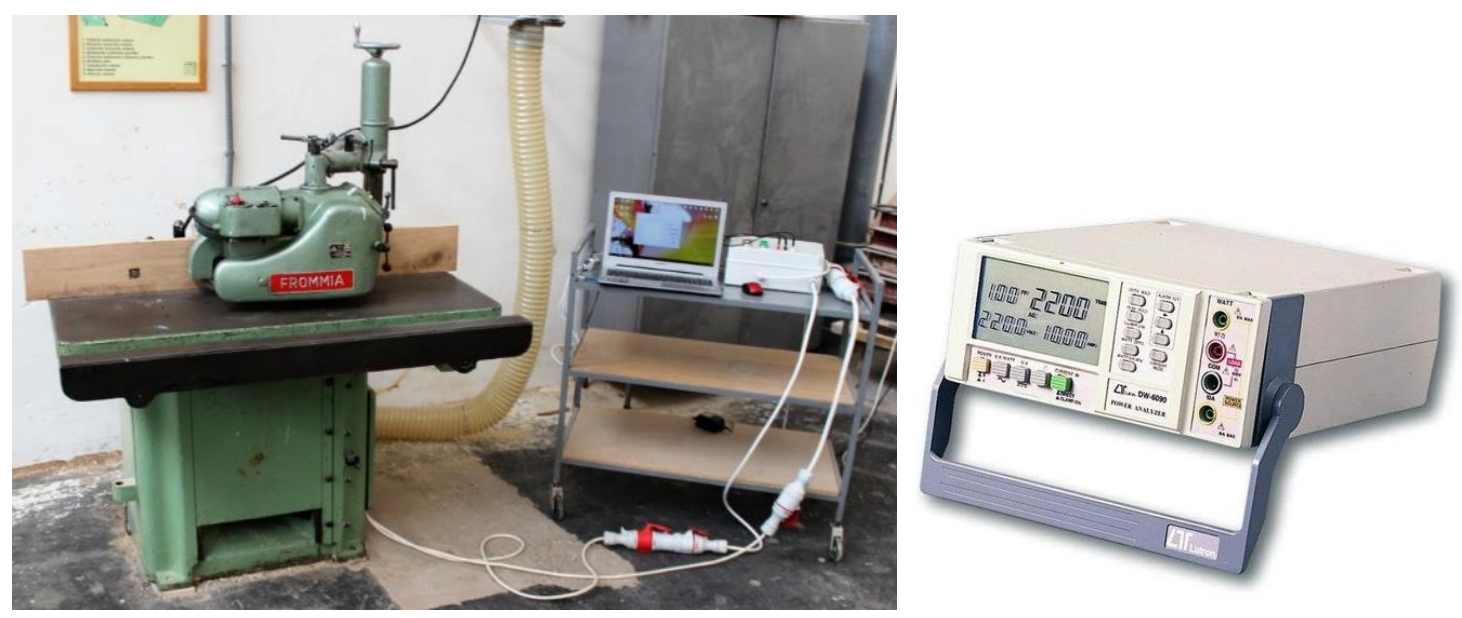

Fig. 5. Wired workplace and Power analyser DW 6090

The lower spindle miller consists of a steel stand that provides stability and carries a spindle and drive. The machine is driven by indirect transmission using a wedge belt from the electric 3 phase asynchronous motor with parameters detailed in Table 2. A speed of $3000 / 6000$ and $4500 / 9000 \mathrm{rpm}$ can be achieved with step pulleys. The motor of the Frommia feed mechanism had the parameters detailed in Table 3 with a gradual change of feed rate. 
Table 2. Technical Parameters of Asynchronous Motor of Milling Machine FVS

\begin{tabular}{|c|c|}
\hline Parameter & Value \\
\hline Current system $(\mathrm{V})$ & $360 / 220$ \\
\hline Input power $(\mathrm{kW})$ & 4 \\
\hline Frequency $(\mathrm{Hz})$ & 50 \\
\hline Transient resistance $(\Omega)$ & 0.03 \\
\hline Manufacturer & Maschinenfabrik Ferdinand Fromm. \\
\hline
\end{tabular}

Table 3. Technical Parameters of Motor of Feed Device Frommia

\begin{tabular}{|c|c|}
\hline Parameter & Value \\
\hline Type & ZDM $252 / 137$ \\
\hline Input voltage $(\mathrm{V})$ & 380 \\
\hline Feed rate $\left(\mathrm{m} \mathrm{min}^{-1}\right)$ & $2,5 / 10 / 15 / 30$ \\
\hline Input power $(\mathrm{kW})$ & 0.55 \\
\hline Spindle speed $\left(\mathrm{m} \mathrm{min}^{-1}\right)$ & 2800 \\
\hline Manufacturer & Maschinenfabrik Ferdinand Fromm. \\
\hline
\end{tabular}

A double-bladed wood cutter with rake angle $\gamma=15^{\circ}, 20^{\circ}$, and $30^{\circ}$ with interchangeable blades was used as the cutting tool for planar milling (Fig. 6). Two blades were fitted into the milling head so that only one wedge was in the cut with a depth of 1 $\mathrm{mm}$. The second knife was set into the milling head to balance the tools. Table 4 shows the basic parameters of the milling cutter. Cutting blades FH 45 (SZT, Turany, Slovakia) were made from the steel Maximum Special 55: 1985/5 with a hardness of 64 HRC (WOOD-B, Nové Zámky, Slovakia).

Table 4. Technical Parameters of Milling Cutter

\begin{tabular}{|c|c|}
\hline Parameter & Value \\
\hline Diameter of the head $(\mathrm{mm})$ & 125 \\
\hline Diameter of the head with blades $(\mathrm{mm})$ & 130 \\
\hline Width of cutter $(\mathrm{mm})$ & 45 \\
\hline Arbor hole diameter $(\mathrm{mm})$ & 30 \\
\hline Number of blades & 2 \\
\hline Maximal revolutions $\left(\mathrm{min}^{-1}\right)$ & 8000 \\
\hline Manufacturer & STATION \\
\hline
\end{tabular}

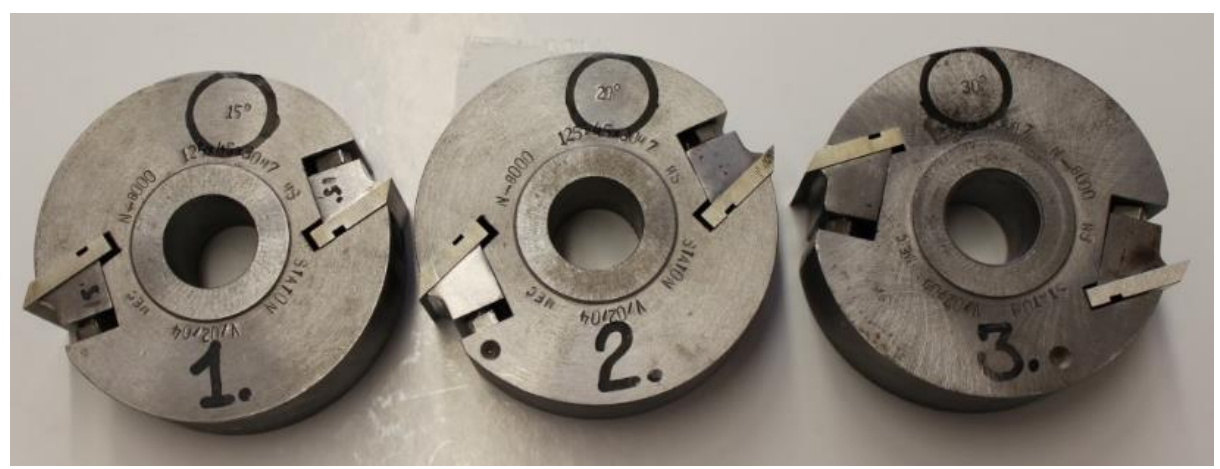

Fig. 6. Milling cutters with rake angle of $15^{\circ}, 20^{\circ}$, and $30^{\circ}$

Koleda et al. (2018). "Machining \& energy efficiency," BioResources 13(3), 6133-6146. 6138 
The measurement of the power consumption was carried out by measuring the actual values of current (I), voltage (U), and the $\cos \varphi$ factor in one phase of the three-phase power supply by the Power Analyser DW 6090. The power measurement period is given by the repeated frequency of the DW 6090 Analyser and the serial transmission rate. The resulting transmission rate is $c a$. 3 data per second. The analyser connection to the computer is via the RS 232 interface and the USB/RS232 converter at a 9600 baud rate, no parity, 8 data bits, and one STOP bit.

Table 5. Technical Parameters of Power Analyser DW 6090

\begin{tabular}{|c|c|}
\hline Parameter & Value \\
\hline Voltage range & 600 VAC/DC \\
\hline Current range & 10 A direct/1000 A with current transformer \\
\hline Power range $(\mathrm{W})$ & 6000 \\
\hline Range of $\cos \varphi$ & $0.01 \div 1.00$ \\
\hline Bandwidth $(\mathrm{Hz})$ & $40 \div 400$ \\
\hline Interface & $\mathrm{RS} 232$ \\
\hline Accuracy $(\%)$ & $1 \div 1.5$ \\
\hline Supply voltage (VDC) & 9 \\
\hline
\end{tabular}

The cutting conditions for milling are shown in Table 6. Each sample of oak wood was milled in all combinations of the cutting edge angles, cutting speeds, and feed rates. According to angular geometry of tool the change of face angle caused the change of clearance angle. Every wood sample has been milled for 27 times. The total number of millings is 135 .

Table 6. Cutting Conditions

\begin{tabular}{|c|c|c|}
\hline \multicolumn{2}{|c|}{ Cutting conditions } & Value \\
\hline \multirow{4}{*}{ Angular geometry $\left(^{\circ}\right)$} & Rake angle & $15,20,30$ \\
\cline { 2 - 3 } & Wedge angle & 45 \\
\cline { 2 - 3 } & Clearance angle & $30,25,15$ \\
\cline { 2 - 3 } & Cut angle & 75 \\
\hline \multirow{2}{*}{ Temperature of thermal modification $\left({ }^{\circ} \mathrm{C}\right)$} & $160,180,210,240$ \\
\cline { 2 - 2 } & $20,40,60$ \\
\hline \multicolumn{2}{|c|}{ Cutting speed $\left(\mathrm{m} \mathrm{s}^{-1}\right)$} & $6,10,15$ \\
\hline \multicolumn{2}{|c|}{ Feed rate $\left(\mathrm{m} \mathrm{min}^{-1}\right)$} & 1 \\
\hline \multicolumn{2}{|c|}{ Depth of cut $\left(\mathrm{mm}^{2}\right)$} & Natural \\
\hline
\end{tabular}

\section{RESULTS AND DISCUSSION}

The measured power values of all combinations of the milling technology parameters were processed and statistically evaluated. The analysis of the variance of the measured data is shown in the graph in Fig. 7.

The highest mean value of the input power $(2925 \mathrm{~W})$ was measured on a sample of native wood. This value was decreased (by $0.3 \%$ ) at a temperature of $160{ }^{\circ} \mathrm{C}$. The largest difference was measured in another sample treated at a temperature of $180{ }^{\circ} \mathrm{C}$, where the 
drop was almost $35 \mathrm{~W}$, which represents a change of $1.2 \%\left(1.75 \mathrm{~W} /{ }^{\circ} \mathrm{C}\right)$. The sample with a treatment temperature of $210{ }^{\circ} \mathrm{C}$ had a slight decrease of $0.3 \%$. The power measured of the sample with a treatment temperature of $240{ }^{\circ} \mathrm{C}$ increased by $0.5 \%$ to the value of 2888 W.

Native wood does not have a thermally degraded structure, and therefore the power required for milling it is the largest. Thermal treatment reduces the mechanical properties of wood, disturbs hemicellulose, decreases the density, and makes wood less firm. The impact of the change in the technical properties of heat-treated wood was most visible among the wood samples treated at temperatures of 160 and $180{ }^{\circ} \mathrm{C}$. The increase in temperature became most evident in the deterioration of these properties and in the decrease of the power required for milling. Wilkowski et al. (2011) investigated the energy demand of native and thermally modified oak wood at a temperature of $165^{\circ} \mathrm{C}$ at a feed rate of $3 \mathrm{~m} \mathrm{~min}^{-1}$, a cut depth of $2 \mathrm{~mm}$, and a rotary mill speed of $3000 \mathrm{rpm}$ with a milling head with one knife in cut. Similarly, a reduction in the required power was shown, from $1099 \mathrm{~W}$ to $1033 \mathrm{~W}$. Kubš et al. (2016) showed a decrease in cutting power during milling beech native and thermally modified wood. Krauss et al. (2016) investigated the cutting power when milling of heat-treated beech wood and found that the energy demand decreases with an increase of heat treatment temperature.

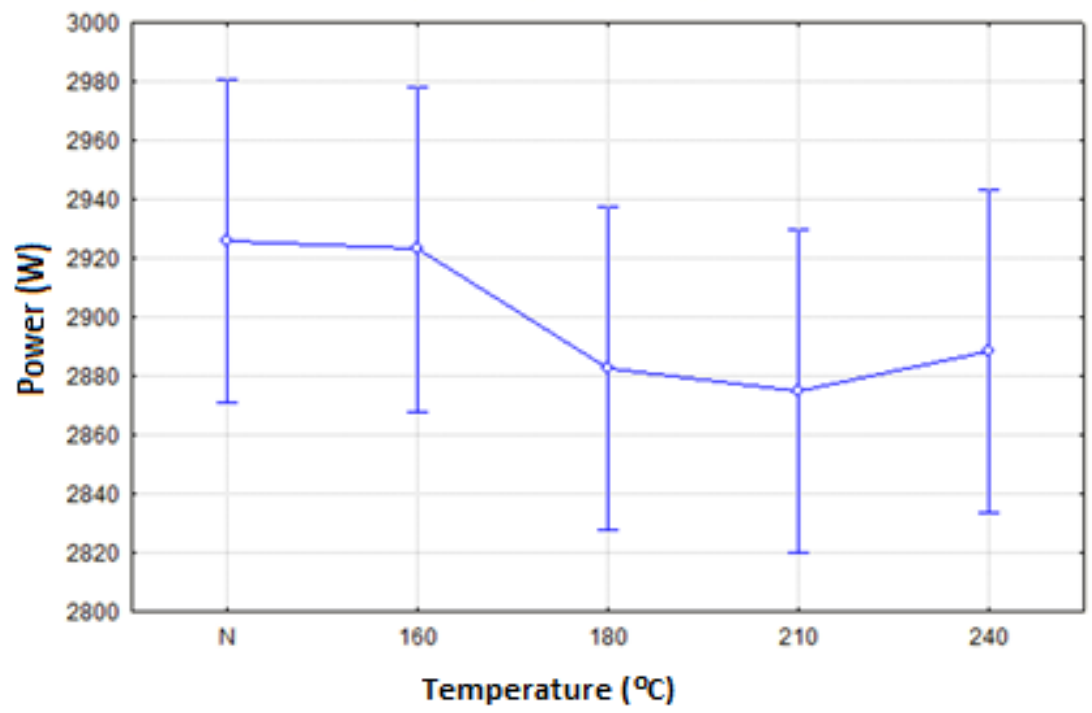

Fig. 7. Effect of heat treatment on input power

Table 7. Duncan's Significance Levels - Dependency of Power vs. Heat Treatment

\begin{tabular}{|c|c|c|c|c|c|}
\hline $\begin{array}{c}\text { Temperature of thermal } \\
\text { modification }\left({ }^{\circ} \mathrm{C}\right)\end{array}$ & $\mathrm{N}$ & 160 & 180 & 210 & 240 \\
\hline Average power $(\mathrm{W})$ & 2925 & 2917 & 2882 & 2874 & 2888 \\
\hline $\mathrm{N}$ & & 0.119 & 0.000 & 0.000 & 0.000 \\
\hline 160 & 0.119 & & 0.000 & 0.000 & 0.000 \\
\hline 180 & 0.000 & 0.000 & & 0.138 & 0.283 \\
\hline 210 & 0.000 & 0.000 & 0.138 & & 0.014 \\
\hline 240 & 0.000 & 0.000 & 0.283 & 0.014 & \\
\hline
\end{tabular}


The level of statistical significance and the statistical difference in the effect of individual temperature treatments on the power consumption was evaluated using the posthoc Duncan test (Table 7). The probability of similarity between native wood and wood treated at $160{ }^{\circ} \mathrm{C}$ was 0.119 , which exceeds the $5 \%$ limit, and there was no statistically significant difference between these values. However, there was a statistically significant difference $(\mathrm{p}<5 \%)$ between native wood and the other temperature-modified samples except $160{ }^{\circ} \mathrm{C}$. A statistically significant difference was observed between the sample treated at a temperature of $160^{\circ} \mathrm{C}$ and the other temperature-treated samples as well as the samples treated at 210 and $240{ }^{\circ} \mathrm{C}$.

Milling of samples was executed at a feed rate of 6,10 , and $15 \mathrm{~m} \mathrm{~min}^{-1}$. The analysis of the measured data is shown in Fig. 8.

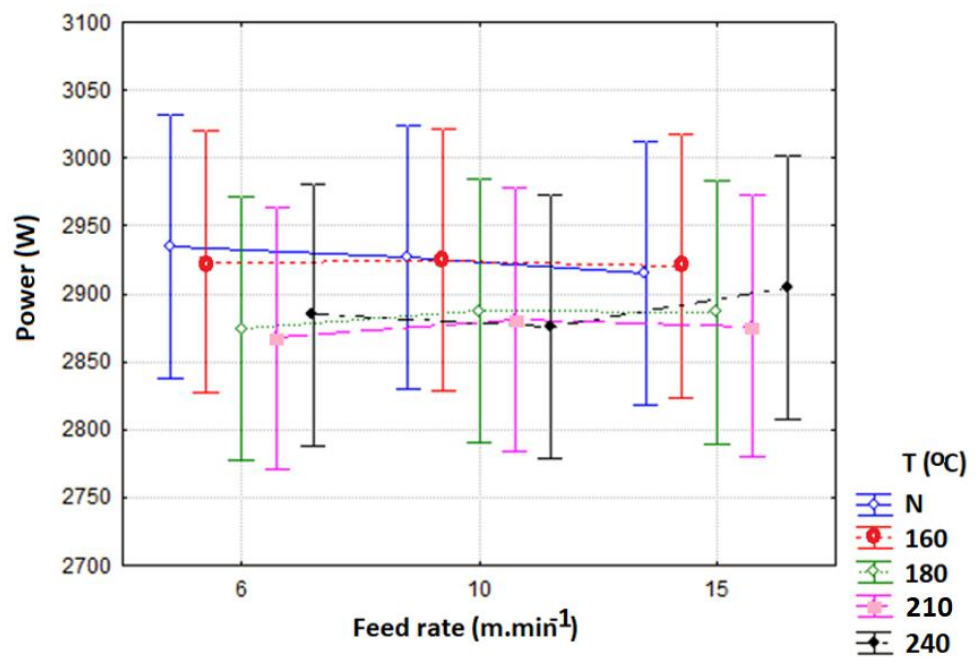

Fig. 8. ANOVA of effect of feed rate on electric power

From the post-hoc Duncan's test, the effect of feed rate was not statistically significant with any heat treatment. Figure 8 shows that when the feed rate was increased from 6 to $10 \mathrm{~m} \mathrm{~min}^{-1}$ in the native wood and wood heat treated at a temperature of $240{ }^{\circ} \mathrm{C}$, the average input power decreased but the overall power input increased for other materials. When the feed rate was increased from 10 to $15 \mathrm{~m} \mathrm{~min}^{-1}$, the power decreased slightly in all materials except for oak wood with heat treatment of $240{ }^{\circ} \mathrm{C}$. The decrease in power can be justified by the uneven material density (different structure of the examined samples) and may be due to a smaller number of measured data due to the higher feed and cutting speeds at an unchanged serial communication speed. The multifactor analysis showed that whereas the heat-treated sample at $210{ }^{\circ} \mathrm{C}$ had the lowest input power, the heat-untreated sample had the highest input power.

The milling of samples was executed at the cutting speed of 20,40, and $60 \mathrm{~m} \mathrm{~s}^{-1}$. The analysis of the measured data is shown in Fig. 9. From the post-hoc Duncan's test, the effect of cutting speed was statistically significant with any heat treatment. In Fig. 9, when the cutting speed was increased from 20 to $40 \mathrm{~m} \mathrm{~s}^{-1}$, the overall power consumption dropped, and at $60 \mathrm{~m} \mathrm{~s}^{-1}$ it reached its maximum value. The reason for increased total power with increasing cutting speed is that the cutting tool was rotating more rapidly and the material was machined faster. The lowest input power has been measured for sample treated at temperature of $210^{\circ} \mathrm{C}$, the highest for heat-untreated sample and sample treated at $160{ }^{\circ} \mathrm{C}$. 


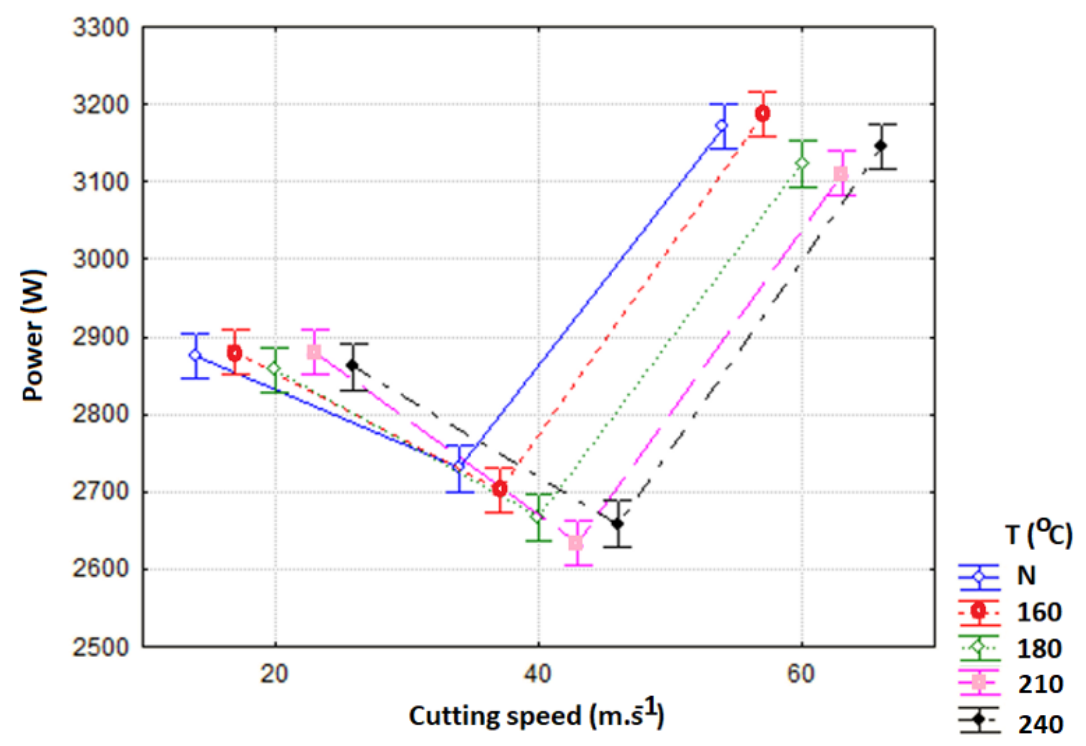

Fig. 9. ANOVA of effect of cutting speed on electric power

The effect of the rake angle is shown in the Fig. 10. From the post-hoc Duncan's test, the influence of the angular geometry was statistically significant at a temperature of $240{ }^{\circ} \mathrm{C}$. Figure 10 shows that by increasing the cutting edge angle of the cutting tool, the overall power was reduced. The total power input decreased gradually due to the increase in the rake angle, except for the heat-treated sample at $180^{\circ} \mathrm{C}$, where the maximum power at the rake angle was $20^{\circ}$. From the multifactor analysis, it is seen that for the heat-treated sample at $210^{\circ} \mathrm{C}$, the input power was the lowest and at the heat-untreated sample it was the highest.

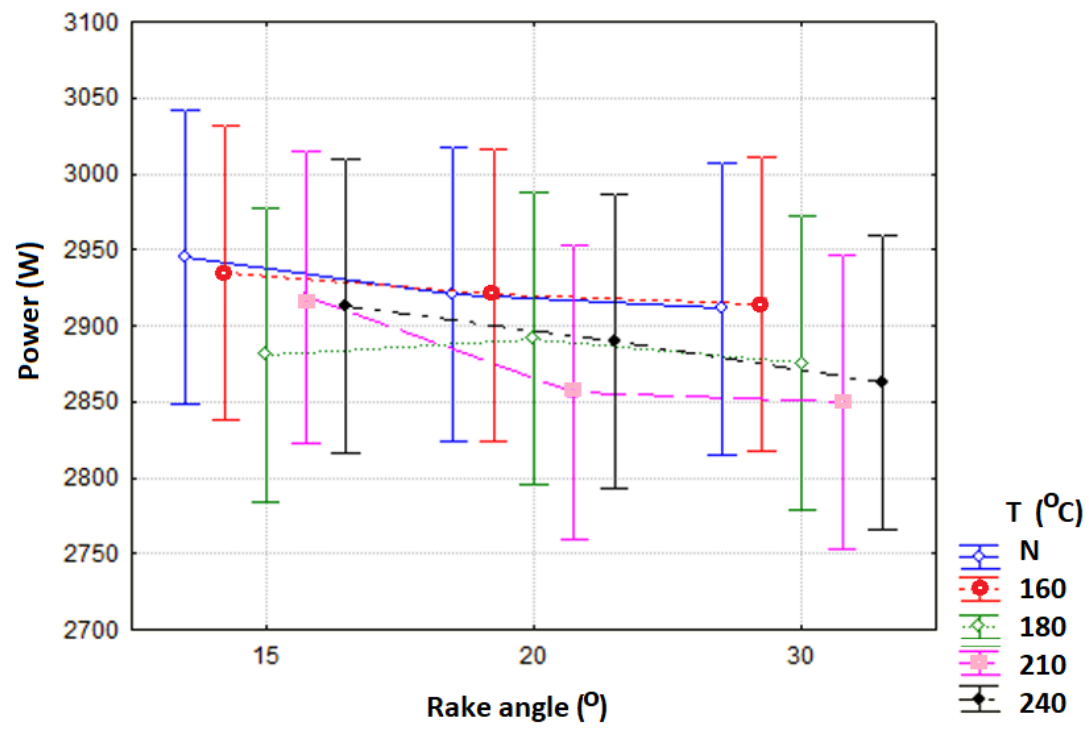

Fig. 10. ANOVA of effect of rake angle on electric power

The wood structure of the examined samples influenced the power values recorded during milling, as the experimental samples were extracted from different logs and were manipulated from different parts of the trunk. In some cases, variations may have been caused by the machining process that took place faster at higher feed rates, and thus, the measuring device recorded fewer data points. Furthermore, variations could be due to 
undesired irregular thermal treatment of samples of oak wood. For example, the center of the heat-treated sample at $240{ }^{\circ} \mathrm{C}$ was lighter than its region. Further research of the heat transfer of selected thermally modified wood by a holography interferometer could confirm the values of the heat transfer coefficients (Černecký et al. 2015). These factors could create inaccuracies and measurement errors, which could also affect measurement results. The evaluated factor has an impact on the energy consumption if the probability of similarity between the sets of measured values is less than 0.05 . The order of each factor is shown in Table 8.

Table 8. Effects of Examined Factors on Energetic Efficiency

\begin{tabular}{|c|c|c|}
\hline Factor & Fisher's F-test & $p$ - significance level \\
\hline Cutting speed & 6766.10 & 0.000 \\
\hline Thermal treatment & 35.91 & 0.000 \\
\hline Angular geometry & 32.20 & 0.000 \\
\hline Feed rate & 1.65 & 0.196 \\
\hline
\end{tabular}

The cutting speed had the most significant impact on energy consumption. The Fisher's F-test and the probability of similarity of the measured data sets show that they lie far enough apart, and therefore there was a statistically significant difference between them. The smallest total input power was recorded at the cutting speed of $40 \mathrm{~m} \mathrm{~s}^{-1}$. The greatest increase of input power for all samples occurred during the cutting speed of 40 and $60 \mathrm{~m} \mathrm{~s}^{-1}$.

The most significant change in energy consumption was seen in the heat-treated material. The increase in heat treatment temperature resulted in a decrease of input power. The total power consumption of the heat-treated sample at $160{ }^{\circ} \mathrm{C}$ decreased by $0.3 \%$; in the heat-treated sample at $180{ }^{\circ} \mathrm{C}$ the power consumption decreased by $1.2 \%$; in the heattreated sample at $210^{\circ} \mathrm{C}$, the power consumption was reduced by $0.3 \%$ and for heat-treated samples at $240{ }^{\circ} \mathrm{C}$, the cutting power increased by $0.5 \%$.

The highest energy consumption in terms of the influence of angular geometry became evident at a temperature of $210{ }^{\circ} \mathrm{C}$, the smallest in a heat-untreated sample. When the rake angle was increased, the total power consumption was reduced. The greatest total power was shown at the angle of $15^{\circ}$, and at the angle of $30^{\circ}$ the input power was the smallest.

The feed rate was statistically insignificant with respect to energy consumption. The energy demand of the asynchronous motor driving the cutter was measured, not the motor driving feed mechanism. The energy intensity dropped at the change of the feed rate from 6 to $10 \mathrm{~m} \mathrm{~min}^{-1}$ in native wood and heat-treated material at $240{ }^{\circ} \mathrm{C}$. For the other materials, when the feed rate was increased from 6 to $10 \mathrm{~m} \mathrm{~min}^{-1}$, the power increased. When the feed rate was increased from 10 to $15 \mathrm{~m} \mathrm{~min}^{-1}$, the power was slightly reduced in all materials except the oak wood with a heat treatment temperature of $240{ }^{\circ} \mathrm{C}$.

Kubiš (2013) and Miftieva (2014) did similar experiments. The resulting evaluation did not coincide with an earlier experiment by Miftieva (2014), claiming that the most energy-efficient factor is the heat treatment of wood, followed by cutting speed and feed rate. Kubiš (2013) claims that the additional influence factor of the power is the heat treatment of the wood, followed by feed rate, cutting speed, and the last factor is the angular 
geometry of tool. Different results could be caused of the largest cutting speed of $40 \mathrm{~m} \mathrm{~s}^{-1}$, which was $60 \mathrm{~m} \mathrm{~s}^{-1}$ in this experiment. Another factor that may have caused the difference may be that the author measured the energy intensity of the milling on the samples that were extracted from the radial central lumber, while in this experiment samples used were from the lateral tangential lumber.

\section{CONCLUSIONS}

1. An analysis of the influence of the thermal modification on the power in plane milling of oak wood showed the greatest dependence of the energy intensity of the milling on the cutting speed. The faster rotation of the cutting tool causes the machine cutter to take more power from the electrical network than hypothesized. However, the lowest total power was measured at a cutting speed of $40 \mathrm{~m} \mathrm{~s}^{-1}$, which was optimal for the selected wood species with respect to its bulk density.

2. The second most important factor was the temperature at which the oak was treated. The highest energy demands were found in the milling of the native wood, which corresponds to the fact that the heat treatment degraded the mechanical properties of the wood, decreasing its strength and thus, the power required for its machining is lower. The optimal temperatures of the heat treatment in terms of energy demands were 180 and $210^{\circ} \mathrm{C}$.

3. The third factor affecting energy consumption was angular geometry, whereby the highest values were measured at milling of heat-treated samples at a temperature of $210{ }^{\circ} \mathrm{C}$ and the lowest at natural wood.

4. The feed rate was statistically insignificant. The energy consumption of the feed mechanism was not measured.

5. Since exotic woods with comparable properties for the construction of exterior wood products are replaced by heat-treated wood, it can be stated that a reduction in the cost of these products is achieved not only by choosing a cheaper wood with subsequent heat treatment but also by lowering the power consumption required for machining operations.

\section{ACKNOWLEDGMENTS}

The authors are grateful for the support of the Ministry of Education, Science, Research and Sport of the Slovak Republic, Grant VEGA 1/0315/17. 


\section{REFERENCES CITED}

Barcík, Š., and Homola, T. (2004). "Effect of selected parameters on the quality of machined surface at planar milling of juvenile pine wood," in: Proceedings of the Chip and Chipless Woodworking 2004, Stary Smokovec, Slovakia, pp. 31-36.

Barcík, Š., Gašparík, M., Houska, A., Razumov, E., Ju., and Sedlecký, M. (2014). "Effect of technological factors on the quality of machined surface of thermally modified pine wood," in: Proceedings of the Chip and Chipless Woodworking 2014, Zvolen, Slovakia, pp. 11-21.

Barcík, S., and Rehák, T. (2009). "Effect of selected technical, technological and material factors on the energetic efficiency at planar milling," Czech University of Life Sciences, Prague, Czech Republic.

Bengtsoon, C., Jermer, J., Clang, A., and Ek-Olausson, B. (2003). Investigation of some Technical Properties of Heat-treated Wood, International Research Group on Wood Protection, Brisbane, Australia.

Boonstra, M. J., Van Acker, J., and Pizzi, A. (2007). "Anatomical and molecular reasons for property changes of wood after full-scale industrial heat-treatment," Proceedings of the Third European Conference on Wood Modification, Cardiff, UK, pp. 343-358.

Černecký, J., Jandačka, J., Malcho, M., Koniar, J., and Brodnianská, Z. (2015). "Effect of the positions of directional tubing towards shaped heating surfaces on the value of local heat transfer coefficients," JP Journal of Heat and Mass Transfer 12(1), 15-30. DOI: 10.17654/JPHMTAug2015_015_030

Distrelec. (2012). "Technical documentation," (https://www.distrelec.sk/sk/wattmetrlutron-dw 6090), accessed 12 February 2012.

International ThermoWood Association (2013). (http://www.thermowood.fi), accessed 01 June 2016.

Koleda, P., Barcík, Š., Vančo, M., and Nociarová, A. (2017). "Effect of thermal modification and grinding on color change of selected wood species," Acta Facultatis Technicae 22(2), 47-61.

Krauss, A., Piernik, M., and Pinkowski, G. (2016). "Cutting power during milling of thermally modified pine wood," Drvna Industrija 67(3), 215-222. DOI: $10.5552 /$ drind.2016.1527

Kubiš, J. (2013). Influence of Selected Factors on the Energy Performance of Flat Milling of Thermally Modified Wood, Master's Thesis, Czech University of Life Sciences, Prague, Czech Republic.

Kubš, J., Gaff, M., and Barcík, Š. (2016). "Factors affecting the consumption of energy during the milling of thermally modified and unmodified beech wood," BioResources 11(1), 736-747.

Lisičan, J. (1996). "Theory and technique of wood working,” MAT-CENTRUM, Zvolen, Slovakia.

Lutron. (2010). "Power analyser DW-6090A," (http://www.sunwe.com.tw/lutron/DW6090Aeop.pdf), accessed 12 February 2017.

Miftieva, E. (2014). Influence of Technical - technological and Material Factors of Planar Milling of Thermally Modified Birch Wood on Energy Performance during Shaping, Master's Thesis, Czech University of Life Sciences, Prague, Czech Republic.

Niemz, P., Hoffmann, T., and Retfalvi, T. (2010). "Investigation of chemical changes in the structure of thermally modified wood," Maderas Ciencia y Tecnologia 12(2), 69- 
78.

Olteanu, E. L., Bîşu, C. F., and Tănese, I. (2013). "Determination of power consumption in Milling," U.P.B. Scientific Bulletin 75(4), 211-220.

Prokeš, S. (1982). Working of Wood and New Wood Materials, SNZL, Prague, Czech Republic.

Reinprecht, L. and Vidholdová, Z. (2008). Thermowood - Preparation, Characteristics and Applications, Technical University, Zvolen, Slovakia.

Safin, R., Barcík, Š. Shaikhutdinova, A., Safina, A., Kavnov, P., and Razumov, E. (2015). "Development of the energy-saving technology of thermal modification of wood in satured steam," Acta Facultatis Xylologiae Zvolen 57(2), 39-47. DOI: 10.17423/afx.2015.57.2.04

Thiede, S., Bogdanski, G., and Herrmann, C. (2012). "A systematic method for increasing the energy and resource efficiency in manufacturing companies," in: 1 st CIRP Global Web Conference: Interdisciplinary Research in Production Engineering (2), pp. 18-33. DOI: 10.1016/j.procir.2012.05.034

Vančo, M., Jamberová, Z., Barcík, Š., Gaff, M., Čekovská, H., and Kaplan, L. (2017a). "The effect of selected technical, technological, and material factors on the size of juvenile poplar wood chips generated during face milling," BioResources 12(3), 4881-4896. DOI: 10.15376/biores.12.3.4881-4896

Vančo, M., Mazáň, A., Barcík, Š., Rajko, L., Koleda, P., Vyhnáliková, Z., and Safin, R. R. (2017b). "Impact of selected technological, technical and material factors on the quality of machined surface at face milling of thermally modified pine wood," BioResources 12(3), 5140-5154. DOI: 10.15376/biores.12.3.5140-5154

Wilkowski, J., Grześkiewicz M., Czarniak P., Siwek I., Javorek L., and Pauliny D. (2011). "Influence of thermal modification of oak wood on cutting forces during milling," Annals of Warsaw University of Life Sciences - SGGW Forestry and Wood Technology 76, 203-207.

Zobel, B. J., and Sprague, J. R. (1998). Juvenile Wood in Forest Trees, Springer-Verlag, Berlin. DOI: 10.1007/978-3-642-72126-7

Article submitted: April 12, 2018; Peer review completed: May 14, 2018; Revised version received: May 31, 2018; Accepted: June 3, 2018; Published: June 21, 2018. DOI: 10.15376/biores.13.3.6133-6146 